\title{
The Role of Social Enterprise Hybrid Business Models in Inclusive Value Chain Development
}

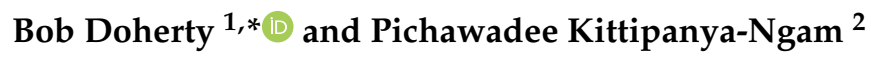 \\ 1 The York Management School, University of York, York YO10 5DD, UK \\ 2 Thammasat Business School, Thammasat University, Bangkok 10200, Thailand; pichawadee@tbs.tu.ac.th \\ * Correspondence: bob.doherty@york.ac.uk
}

check for updates

Citation: Doherty, B.;

Kittipanya-Ngam, P. The Role of Social Enterprise Hybrid Business Models in Inclusive Value Chain Development. Sustainability 2021, 13, 499. https://doi.org/10.3390/su 13020499

Received: 29 November 2020

Accepted: 5 January 2021

Published: 7 January 2021

Publisher's Note: MDPI stays neutral with regard to jurisdictional clai$\mathrm{ms}$ in published maps and institutional affiliations.

Copyright: (C) 2021 by the authors. Licensee MDPI, Basel, Switzerland. This article is an open access article distributed under the terms and conditions of the Creative Commons Attribution (CC BY) license (https:// creativecommons.org/licenses/by/ $4.0 /)$.

\begin{abstract}
This study contributes to the growing interest in hybrid organisations, sustainable business models and inclusive value chain development (IVCD). Recent work has identified that of some 570 million farmers in the world, more than 475 million farmers are smallholders in low-middleincome countries experiencing increasing food insecurity and rural poverty. Research argues that there is a lack of research that provides work on appropriate solutions for smallholders. This paper answers this call by a qualitative study of ten case studies, which draws on hybrid organising, sustainable business model and IVCD research to identify the novel business model characteristics that hybrid organisations use to create and manage more inclusive value chains for smallholders. These hybrid organisations are designed to create a value proposition that delivers sustainability upgrading for smallholders via both product, process and governance upgrades, empowers smallholders to achieve development goals and creates multiple value for social impact. We therefore identify the important characteristics of the hybrid business model to provide appropriate solutions for smallholders and overcome the challenges identified in the inclusive value chain development literature.
\end{abstract}

Keywords: social enterprise; hybrid organisations; sustainable business models; inclusive value chain development (IVCD); smallholder farmers; empowerment

\section{Introduction}

This paper identifies the business model architecture used by hybrid organisations to create and manage inclusive value chains for smallholder farmers. Recently, the concept of inclusive value chain development (IVCD) has emerged in the international agricultural research literature as a way of integrating competitiveness with poverty reduction for smallholder farmers [1,2]. However, so far, this literature has been dominated by financial and economic aspects, with very limited treatment of other key pillars of sustainability, including social and environmental dimensions and how these dimensions in combination could result in more inclusive approaches [3]. This is demonstrated by the fact that common forms of value chain strategy for smallholders identified in the literature so far include contract farming, spot market selling and improved integration with large agribusiness [3,4]. There has been some early recent work on ecological inclusive business models [5], and in this journal, there is emergent work on smallholder farmers and value chains [6-8]. This research stresses the importance of digital platforms, cooperation and innovations in extension services as positive contributions but [6] highlights the need for more work on adjusting the social dimensions of value chain partnerships. However, to date, business model approaches such as hybrid organisations (social enterprises as "ideal type") have received limited attention. In fact, ref. [3] calls for more in-depth research on which business models are appropriate for IVCD. This paper tackles this gap by showing how sustainable business models are designed by hybrid organisations to promote IVCD.

Despite continued growth in global trade, there are concerns regarding the distribution of economic value between stakeholders in regional and international value chains with 
increasing value being accrued further upstream $[9,10]$. One of those stakeholder groups experiencing growing vulnerability is smallholder farmers, operating in agrifood value chains $[11,12]$. An estimated 2.5 billion people worldwide depend on harvests from approximately 475 million smallholder farmers [13]. A recent article in Nature shows growing problems of food insecurity and poverty in smallholder farmer communities and the urgent need for research to stop neglecting smallholder farmers [14]. This paper investigates how hybrid organisations operating in the agrifood sector design their business models to promote IVCD.

The authors of ref. [3] argue that many value chain approaches see performance driven by mainly financial incentives and pay scant attention to social and environmental objectives. They highlight the risk of high failure rates in developing countries, where smallholders are active participants, and call for value chain approaches that pay attention to both contextual factors and other performance measures in addition to merely financial aspects. More recently, the notion of ICVD has emerged, which refers to a type of intervention that aims to address poverty through improved linkages between businesses and poor households within a value chain via targeting marginalised actors such as smallholders [1,2]. IVCD has been defined as a "positive or desirable change in a value chain to extend or improve productive operations and generate social benefits such as poverty reduction, income and employment generation, economic growth, environmental performance, gender equity and other development goals" [1]. Emerging in the literature is the potential role that private sector business model innovation in economic or technical advances could play in IVCD. However, there is a limited number of cases in the literature that demonstrate successful cases of business models delivering IVCD and their characteristics $[1,2,15]$. Moreover, it is surprising that other business models such as hybrids, which prioritise social and environmental aspects, do not yet appear in the IVCD literature [16].

The field of sustainable business models has emerged to explore how organisations adapt their business architecture to address the creation of multiple forms of economic, social and environmental values $[17,18]$. Limited research so far has investigated how hybrid organisations design their business models to manage these multiple values $[19,20]$. Hybrid organisations are defined [21] as "any organisation that possess significant characteristics of more than one economic sector" (public, private or third sector). Social enterprises are seen as an "ideal type" of hybrid, which bridge the public, private and non-profit sectors and are found in range of industries and locations. They differ from other forms of enterprise as they prioritise the achievement of social and environmental objectives above commercial goals and they differ from other forms of non-profits as they generate income from trading activity [22-24]. Hybrids exist in a range of sectors, including health services, social care, retail, clothing, finance and agrifood, and are recognised as a source of positive social and environmental change [25].

There is a growing number of studies investigating how hybrids manage tensions resulting from the dual mission. However, research concerning how social enterprise hybrids contribute to inclusive value chains is only still emerging. Therefore, our research question is how do hybrid business models create and manage inclusive value chain development for smallholder farmers?

We respond to the question by analysing data gathered directly from ten hybrid social enterprise case studies working in the agrifood sector with smallholders. We contribute to the literature on IVCD, sustainable business models and hybrid organisations by integrating these three emerging areas of the literature to provide insights into the complementarities of these three fields. First, we identify the characteristics of hybrid business models that enable multiple forms of value capture to promote more IVCD. These hybrid business models are designed to create a value proposition and creation that delivers sustainability upgrading for smallholders via both product, process and governance upgrades, empowers smallholders to achieve development goals and creates multiple value for social impact.

The paper is anchored in the hybrid organising, sustainable business model and IVCD literature and these are reviewed in the next section. This is followed by an explanation of 
the methodology and presentation of the findings. In the discussion, we draw out from our data the contributions to knowledge. The final section concludes the paper, comments on the limitations and suggests areas for future research.

\section{Literature Review}

\subsection{Inclusive Value Chain Development}

Value chains can be described as the sequence of interlinked agents, activities, networks and markets that transfer inputs and services into products with attributes that consumers are prepared to purchase [1,2,26-28]. Devaux et al. (2018) argue that standard global value chain analysis has failed to tackle the problems of smallholders in a holistic way. This is surprising bearing in mind that improving the performance of agricultural value chains stands to benefit large numbers of people [29]. The role of smallholders is particularly pertinent in regions such as the Greater Mekong, where, for example, in Thailand, 64 percent of farms are smallholdings [30].

The majority of the work on value chains has focused on competitiveness in terms of identifying where actors can introduce efficiencies, reduce costs and maximise value [4]. These improvements are often termed upgrades and can occur through process upgrading (efficiency of internal processes), product upgrading (new improved more profitable goods) or functional upgrading (increasing profits by changing mix of activities) [31]. Financial investment is often required to make these upgrades, but IVCD interventions often assume that smallholders have the financial resources to make these investments [4,32]. This literature is dominated by economic value despite the growing importance of both social and environmental performance.

The IVCD approach encourages organisations to develop more inclusive collaborative value chain development as this approach aims to improve the linkages between households and value chains. However, as the authors of [2] explain in their review of value chain guides, none of them discuss appropriate business models. The IVCD literature so far can be categorised into four key areas: challenges of IVCD, combining agricultural innovation and IVCD, evaluation and monitoring plus emerging IVCD themes with policy implications.

Challenges identified for IVCD for smallholders include power imbalances, capacity building (organisational and community), meeting quality and certification standards, access to credit, availability of technology inputs and infrastructure and constraints in accessing markets [33-36]. To improve our understanding of these, the authors of [32] propose that there needs to be a more in-depth understanding of the context for local actors. The authors of [37] suggest that a more holistic approach to value chain design is required.

The limited available cases of IVCD identify the importance of combining agricultural innovation and value chain development [38]. Inclusivity of discussions, sharing data, application of gender lens, collective marketing and the importance of time to allow results to emerge have been identified as important in linking innovation with value chain development $[39,40]$. The authors of [3], in their work with smallholders, highlight the importance of business adaptation but focus on approaches such as contract farming and selling on spot markets, plus technical innovations such as refrigeration in transporting crops such as bananas, but not the business model itself. In addition, the authors of [37] propose the positive impact of certification to build coffee farmer resilience. The evaluation and monitoring of IVCD has stressed the importance of both multi-stakeholder approaches and mixed methods [3]. However, indicators are largely economic or technical measures such as yields, gross margin and limited discussion of social and environmental performance.

In their systematic review of the IVCD literature, the authors of [41] identify the importance of niche product development, improving market linkages, the voices of women, how to integrate interventions involving innovation and value chain development. It is also important to note the intersectionality of some of these dynamics, which can disproportionality impact particular groups, e.g., women. In addition, despite the mention of power imbalances and gender equity, there is also limited mention of empowerment 
in the IVCD literature. This process of empowerment is dependent on three elements: access to resources (material, human and social), an ability to define one's objectives and act on them (agency) and the extent to which the objectives are met [42]. According to [43], another approach to conceptualise empowerment is by considering three different forms of power: (1) power within, which is a sense of self-esteem and worth; (2) power capabilities to achieve; and (3) power with collective action to achieve more than is possible for an individual alone.

To date, the IVCD literature has focused mainly on private sector firms with two schools of thought: one linking IVCD with a livelihood focus [32] and the second linking agricultural innovation with IVCD [38]. The authors of [2] argue that there is an absence in the literature regarding discussion on the conditions necessary for value chain development in achieving sustainability. There is increasing interest in how collaboration and partnership can provide these conditions, along with how smallholders navigate the complexity of supplying higher value markets where quality standards coupled with certification play a growing role [2]. In addition, there have been calls for IVCD to consider positive social and environmental impacts and how these can be scaled up. It is therefore surprising that there has been limited work done here on business models themselves, particularly those organisations that are termed hybrids, which prioritise positive social and environmental impact; little attention has been paid to the potential role which they could play in IVCD [16].

\subsection{Hybrid Organisations}

The prioritisation of goals other than revenue growth and profitability distinguishes social enterprise hybrids from organisations in the private sector $[44,45]$. Social goals are broadly construed to include serving the needs of the disadvantaged [46], unemployed [23], homeless [47] and smallholder farmers [48]. Environmental objectives include responding to climate change, biodiversity loss and pollution $[49,50]$ through initiatives such as leadership development and recycling [50]. Hybrids are also recognised for their willingness to collaborate with each other and across sectors [51,52].

To achieve sustainable outcomes in all three domains, social enterprises adopt business models that encompass commercial trading as well as creating social and environmental impacts. This is achieved by blending practices from organisations in the private, public and non-profit sectors $[22,53,54]$. Although deviation from the institutional conventions anchored in each sector of the economy might appear to be a risk-laden strategy, the outcome has been the development of an increasing global population of social enterprise hybrids that strive to generate social change [44].

Organisations manifest generic structural features and characteristics that are in some way "pure" and representative of a distinct and recognisable group of organisations [21,55-57]. In this view, categories are presented as idealised structures from which organisations derive legitimacy from alignment with categorical logics and discourse [58]. To elaborate, the authors of [21] present organisational templates for the categories of private, public and non-profit organisations. Thus, private sector organisations are guided by market forces to maximise financial return, owned by shareholders, governed according to size of share ownership, and generate revenue from sales and fees. Organisations in the public sector are characterised as guided by the principles of public benefit and collective choice, owned by citizens and the state and resourced through taxation. Finally, non-profit sector organisations pursue social and environmental goals, are owned by members, governed by private election of representatives, staffed by a combination of employees and volunteers and generate revenue from membership fees, donations and legacies. Specifically, nonprofit distributing organisations are legally prohibited from distributing any residual "earnings" to those with a managerial or ownership interest [59]. Organisational forms that do not fit neatly into the institutionalised categories outlined above are labelled hybrids and are found in a range of constellations including private-public, private-non-profit and public-non-profit. 
Social enterprise hybrids are "not aligned with the idealized categorical characteristics" of the private, public or non-profit sectors [22] and by pursuing the achievement of commercial, social and environmental objectives are thus a classic hybrid organisational form $[21,46,60,61]$. The authors of [62] identify that societal and environmental value in hybrids can be an automatic spillover from commercial activities, e.g., paying a fairtrade premium to producers, but can also be a contingent spillover, requiring third parties to develop interventions to ensure societal benefit, such as funding a charity which provides work on climate change adaptation for smallholders. The overall alignment of the business model to facilitate the spillover of societal value, in the view of [62], is fundamental to value creating activities.

To date, social enterprise research has focused on understanding how tensions resulting from the dual mission are resolved $[22,60,63,64]$. There is a general assumption that tensions arise due to trade-offs between the pursuit of social and financial objectives; however, the precise nature of how business models are designed, particularly in agrifood value chains, has received limited attention.

\subsection{Sustainable Business Models}

Business models (as a theoretically defined field) describe the organisational architecture which sits between strategy and activities $[65,66]$. As such, it forms the basis for understanding how an organisation positions itself to create and capture value in a market [18]. Business models are a representation of the processes and practices that organisations develop to deliver their value creation and capture activities [67]. Traditionally, this theory has been applied to economic value capture [66], but in recent years, there has been a shift to consider economic, social and environmental value capture through the emergence of sustainable business model research $[67,68]$.

This field demonstrates that a successful transition to more sustainable business practice requires a robust business model which targets integrated activities towards automatic spillover-type triple-bottom-line value creation (Bocken et al. 2014). Apart from a few recent papers $[19,20]$, there has been limited research that has empirically explored organisations set up with hybrid value capture at their core, such as social enterprises [69].

What constitutes the core elements of a business model is founded on the identification in [70] of the building blocks of business models (value propositions, target customers, distribution channels, market relationships, value configuration, core competency, partner network, cost structures and revenue model). These were coalesced by [65] into the business model canvas. In Figure 1, the nine elements of the business canvas in [65] have been grouped based on the reorganisation in $[17,71]$ of the business model building blocks into their three core elements of value propositions, value creation and delivery and value capture dimensions. This business model canvas has been frequently used in the literature to explore successful business models directed at sustainable value capture [72-75]. In this paper, we therefore focus on how business model architecture is designed by hybrid organisations to address IVCD. 


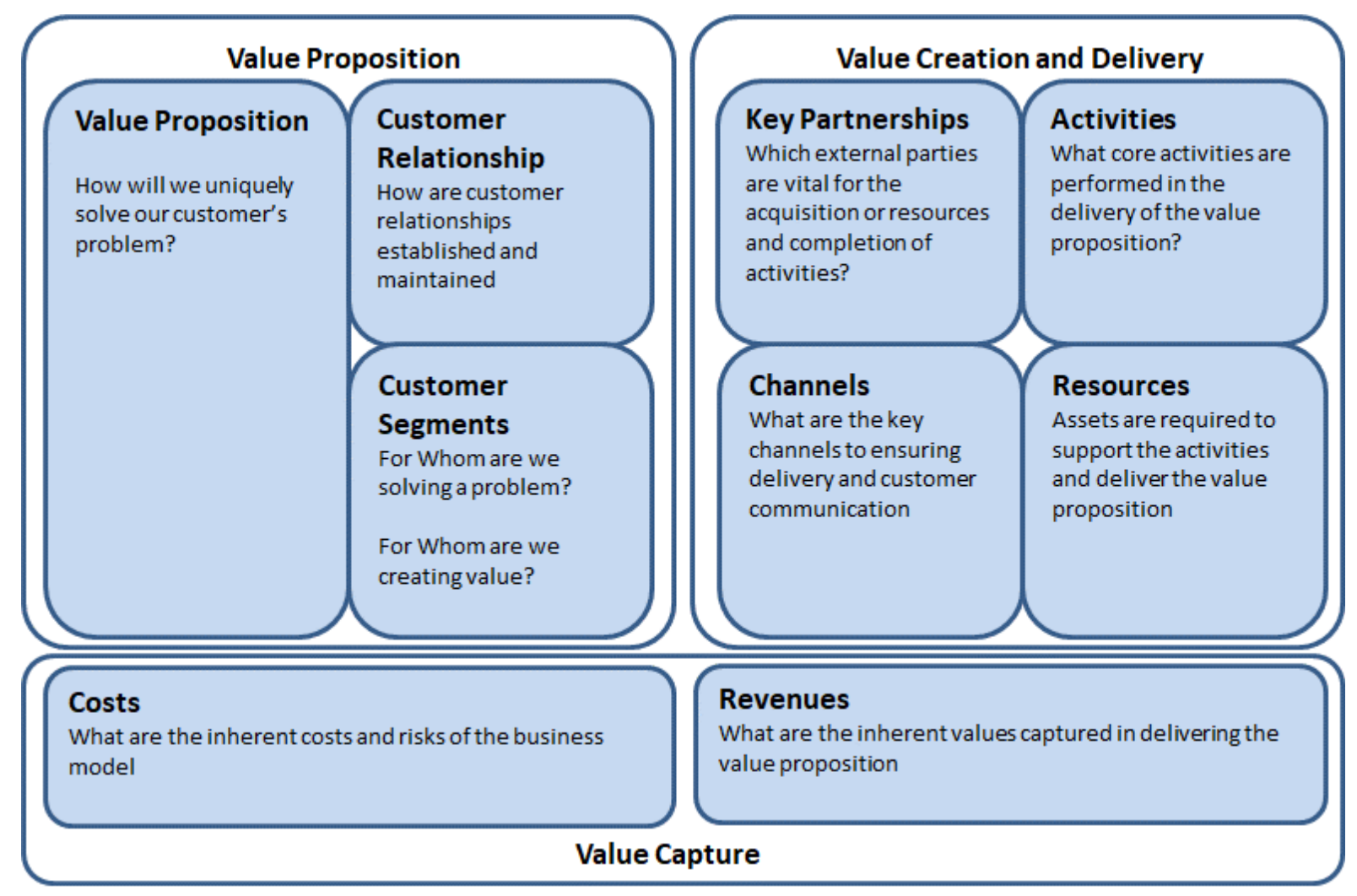

Figure 1. Business model canvas (adapted from Osterwalder and Pigneur, 2010).

\section{Research Objective and Context}

The research is explanation-oriented [76], in which theory building and theory elaboration are employed to advance knowledge [77]. Exploratory research aligns with seeking to understand practices that are in play but not yet understood and labelled. Although interest in hybrids is increasing [60], few studies have investigated their contribution to IVCD and there is little extant empirical knowledge on this topic [16]. However, understanding hybrid social enterprise value chain strategies has theoretical value because of the challenges posed by the pursuit of multiple goals and the value for practitioners responsible for devising inclusive value chains.

\section{Methodology}

The exploratory nature of the research question lends itself to a qualitative multiple case study approach [78]. Research questions determine the research methods and strategies available for researchers. This research aims to answer the question, "how do hybrid business models create and manage inclusive value chain development for smallholder farmers?" This research aims to conduct multiple-case studies instead of a single-case study as multiple-case studies can help guard against researcher's bias [79] as well as increasing external validity, whereas a single-case study limits the generalisability of research findings and conclusions drawn from the data [79].

\section{Data Collection}

This research began with the literature review on value distribution issues in agrifood supply chains, hybrid organisations, inclusive value chain development (IVCD) and sustainable business models in order to identify the key research gaps, which offered a foundation for the development of data collection. The case study method [80] was chosen in this research as it facilitates the richness of case data [81]. Triangulation of data collection 
through focus groups, semi-structured interviews and documentation, which was adopted in this research, increases the validity and reliability of the research [80].

First, to deepen the understanding of how leaders of hybrid organisations understood their impact on value chains, four focus groups (two in Thailand and two in the UK) were conducted to explore and better understand their business models and their paths of inclusive value chain development. One of the workshops in Thailand also included attendance by both Cafédirect and Divine Chocolate staff, whilst one of the workshops in the UK included attendance by the founder and CEO of both Akha Ama Coffee and Jaspberry Organic.

Secondly, 22 in-depth and semi-structured interviews with the leaders (managing directors or senior leaders) of leading social enterprises in agrifood value chains both in Thailand and the UK were then conducted. Researcher access to senior leaders is notoriously difficult and, in consequence, sample size tends to be small [76].

Finally, secondary data for each of the participating organisations were reviewedfor example, published financial statements, social impact reports and other documents (Table 1 presents the data sources). The ten social enterprise hybrids in both Thailand and the UK (see Table 1) in this study are competing in sectors such as hot beverages, dairy, chocolate confectionery, snack nuts, rice and organics. Thailand was chosen to participate in this research mainly because of the growing number of social enterprises in the Thailand agrifood sector in recent years [82]. In addition, while Thailand has been ranked amongst the world's top 5 countries producing and exporting food products for the global market, smallholders and growers still suffer from inequalities in value chains [83]. Moreover, given the maturity of the social enterprise sector in the UK, its cases also provide valuable lessons. In addition, these chosen cases involve different food products, different sizes of companies, as well as different context countries (in Thailand and the UK), consequently providing different perspectives in inclusive value chain development, thus improving the external validity of the research.

\section{Data Analysis}

To ensure internal validity and reliability, a constant comparative method was utilised [84]. Multiple responses were compared against each other, with field notes and secondary sources. We subsequently interpreted these data outputs and provided underlying rationales for each organisation's actions from the data [81]. External validity and reliability were increased through triangulation with both secondary sources (internal reports, external reports, news media, sales ledgers, etc.) and taking versions of the work back to the case organisations for their feedback and comments [85].

Interviews and focus groups were recorded, transcribed and run through a series of categorisation, abstraction and comparison processes to identify themes which contribute to theory development [86]. During these processes, specific attention was given to the decisions made by our informants and the how they talked about their business models. Both authors analysed the interview transcripts independently. This was first carried out manually to stay close to the empirical data and generate codes, and then using the Nvivo software package to scrutinise the veracity of our coding and theorising. Aspects of theory were then reviewed iteratively to decide on the direction of future data collection, and emergent themes regarding the business models and value capture were then presented to participants for review and refinement before writing the final document. As a result, we built a business model canvas for each of our case social enterprises (see Figure 2a-j). 
Table 1. Data sources.

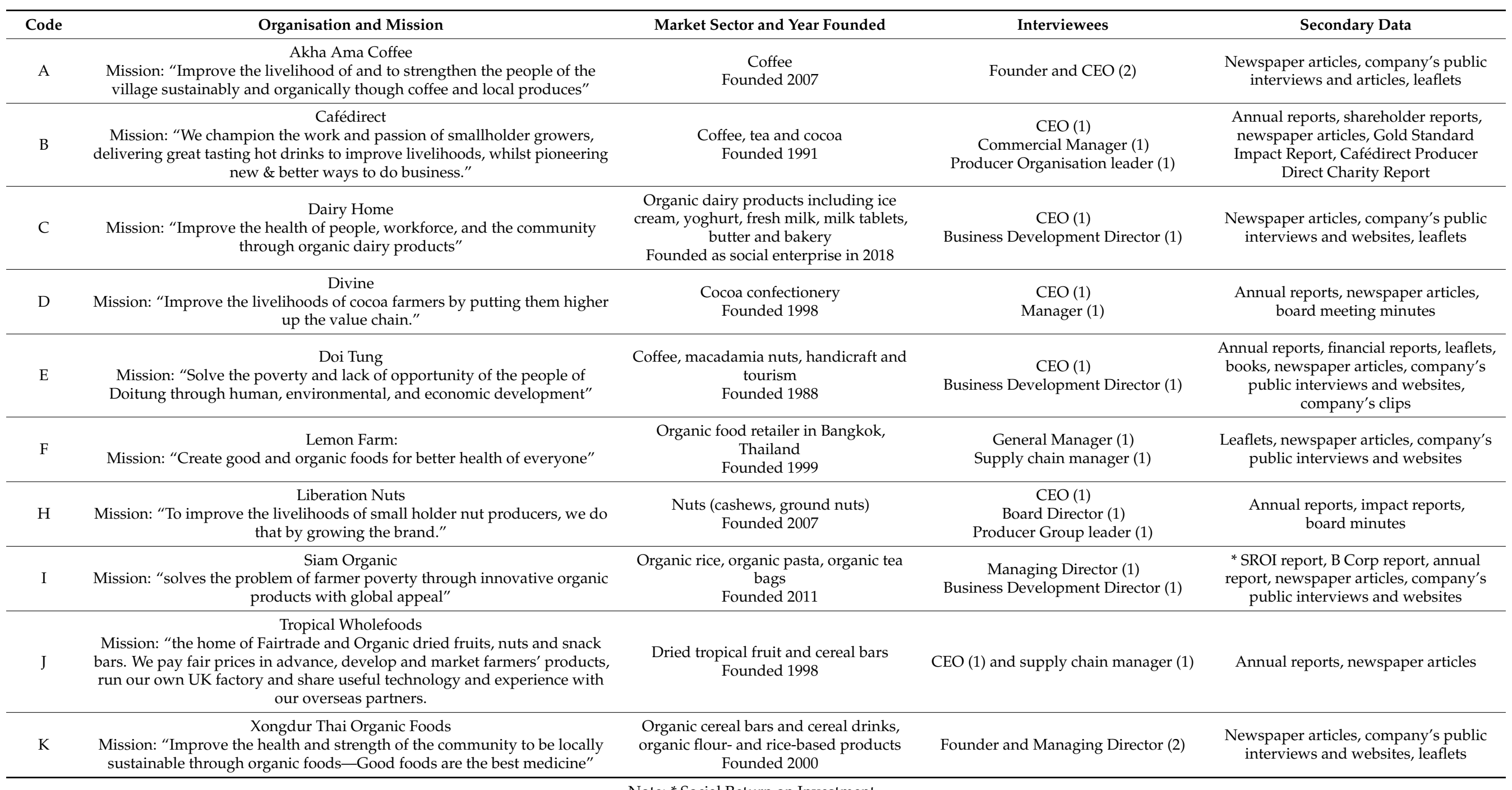

Note: * Social Return on Investment. 


\section{Cafédirect Business Model}

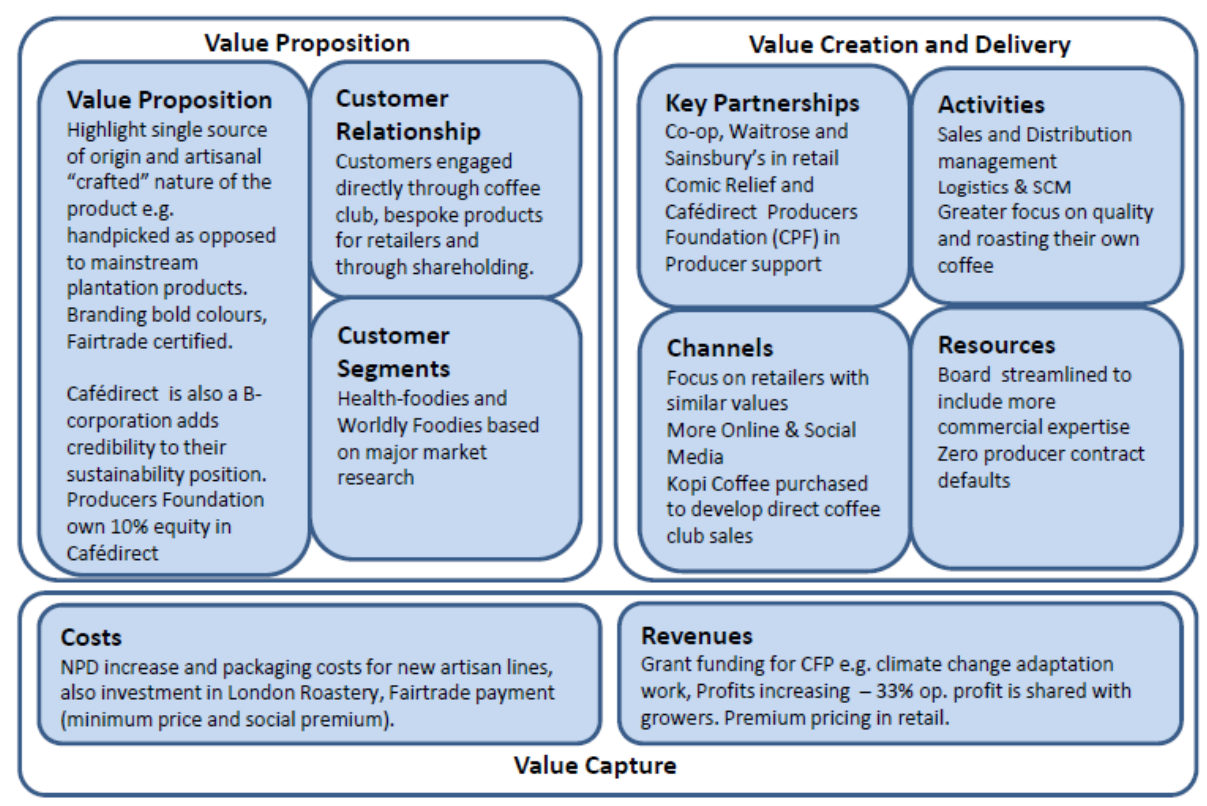

(a)

\section{Akha Ama Coffee Business Model}

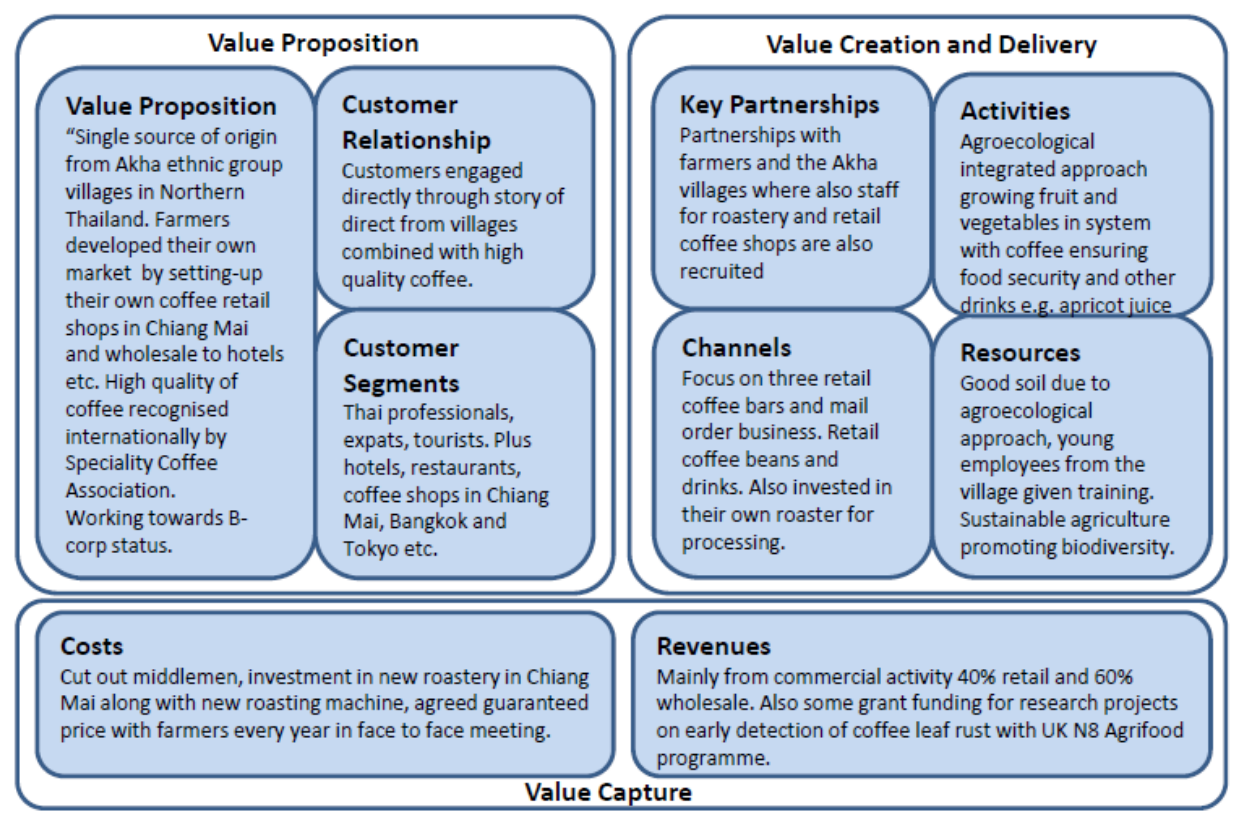

(b)

Figure 2. Cont. 


\section{Doi Tung Business Model}

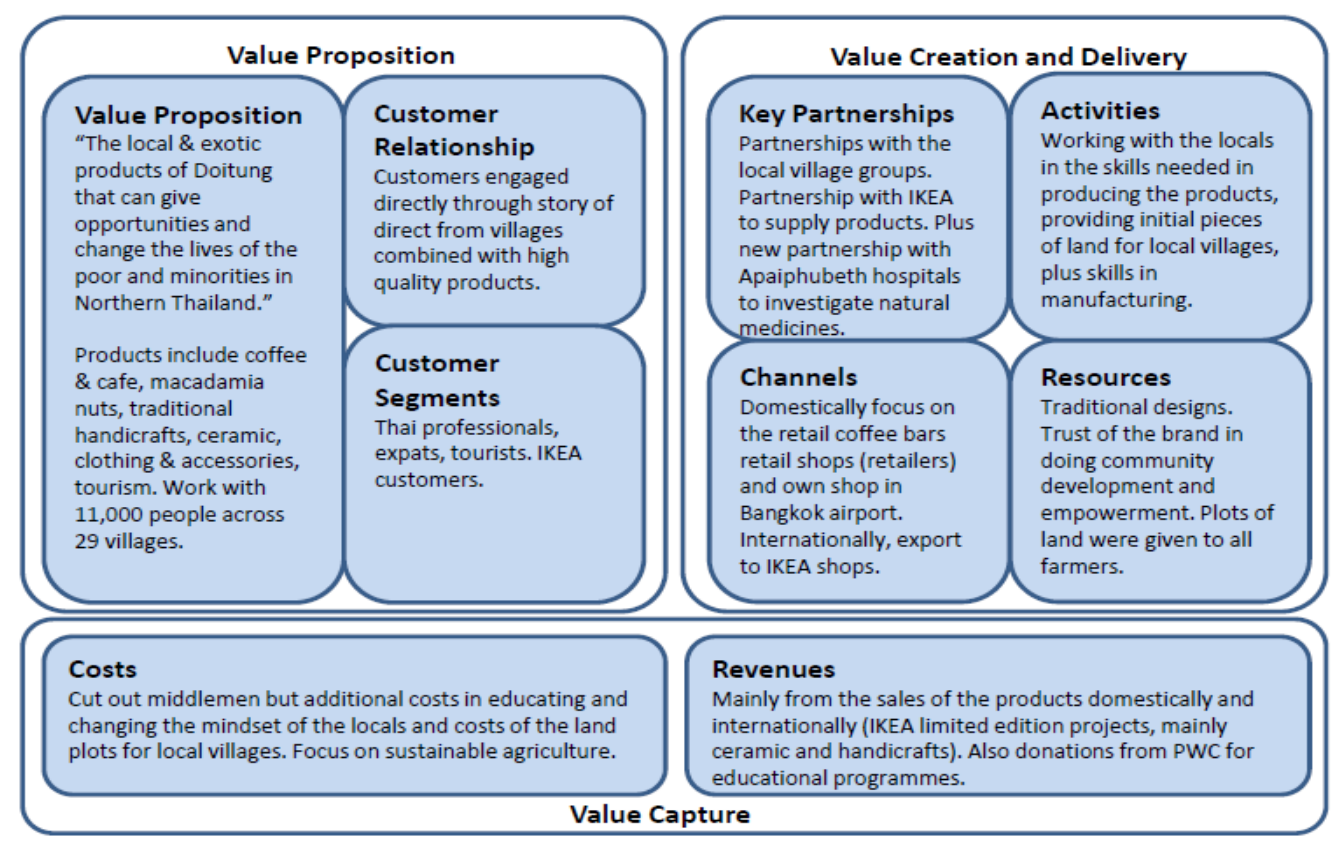

(c)

\section{Dairy Home Business Model}

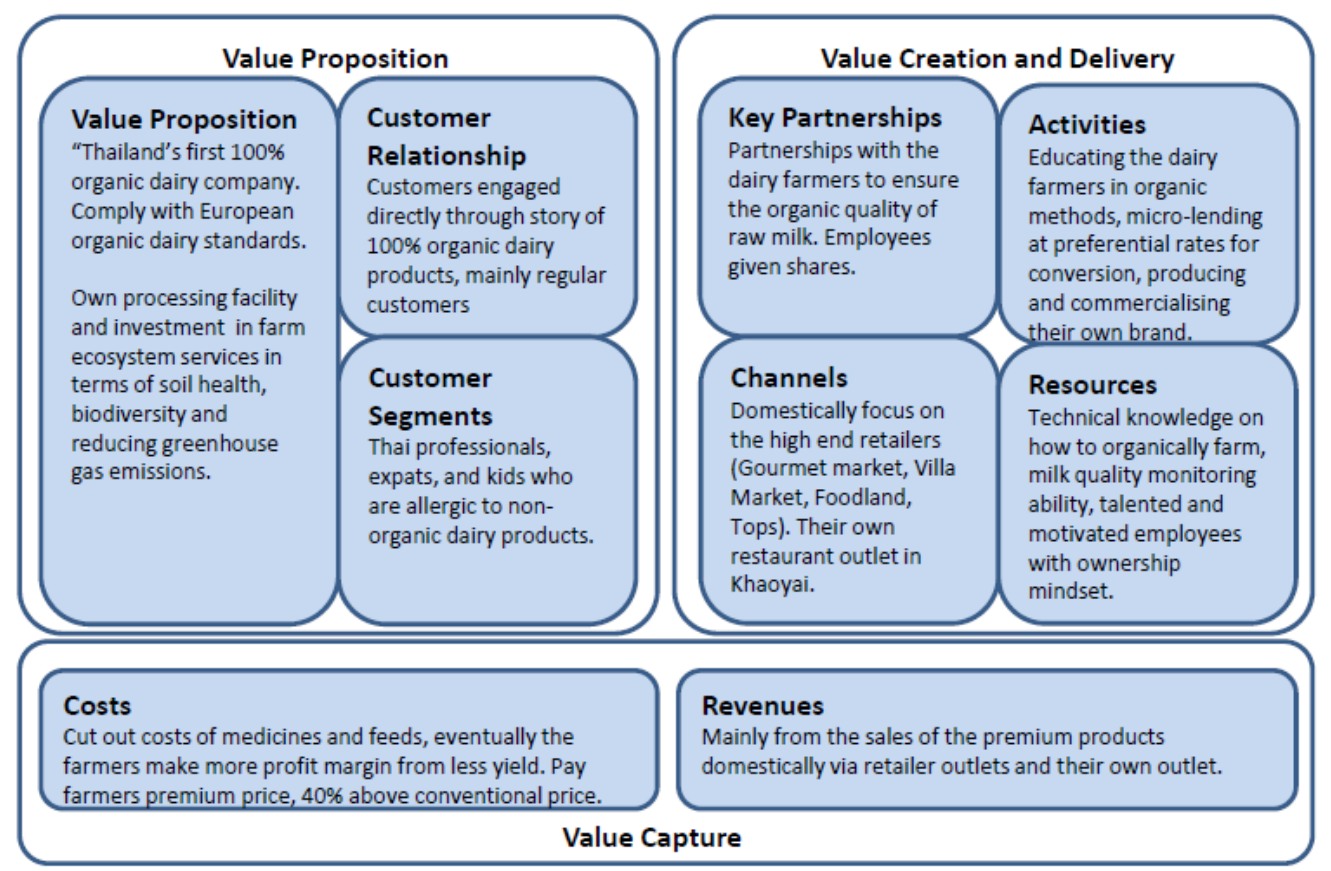

(d)

Figure 2. Cont. 


\section{Jasberry Organic Business Model}

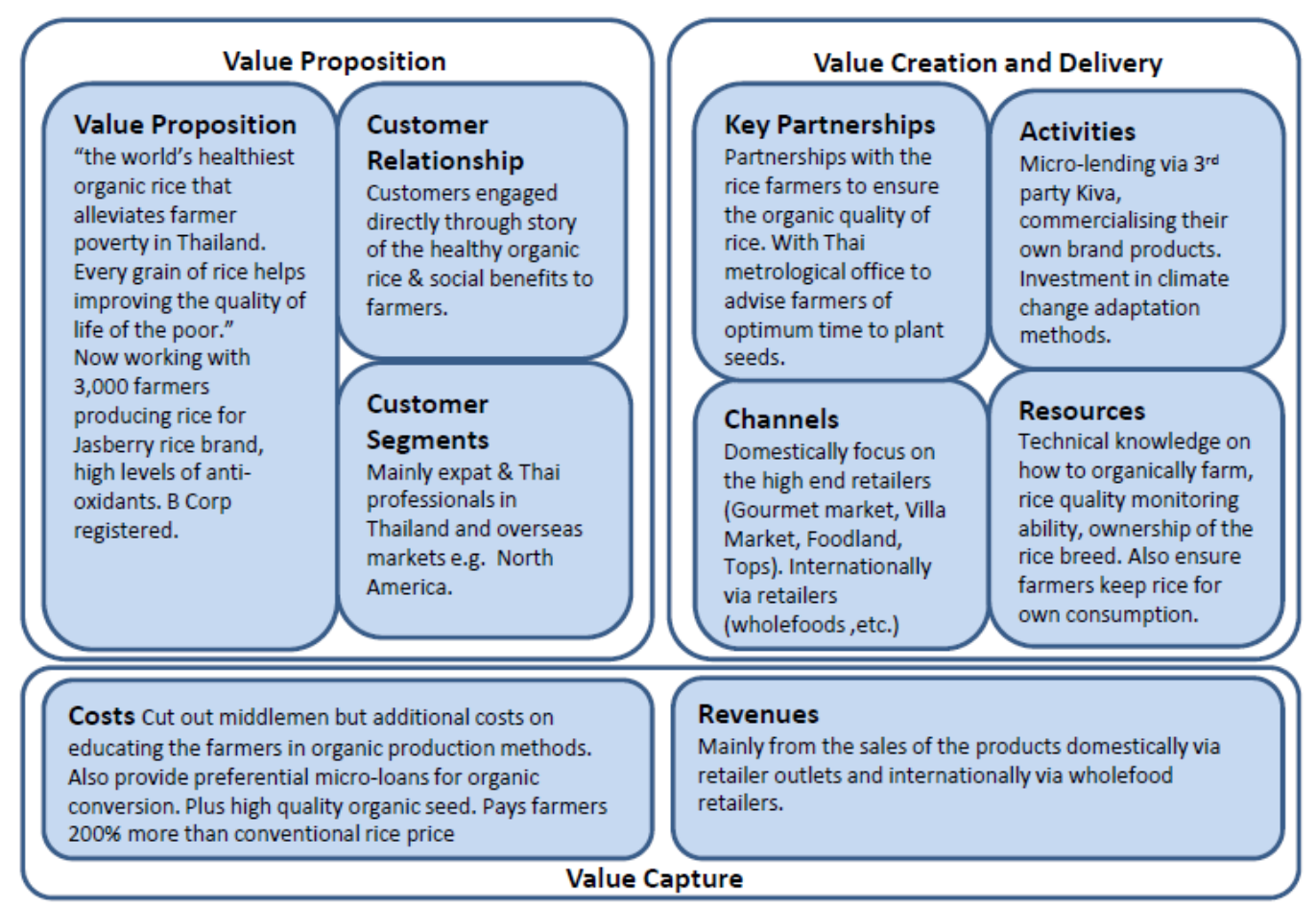

(e)

\section{Lemon Farm Business Model}

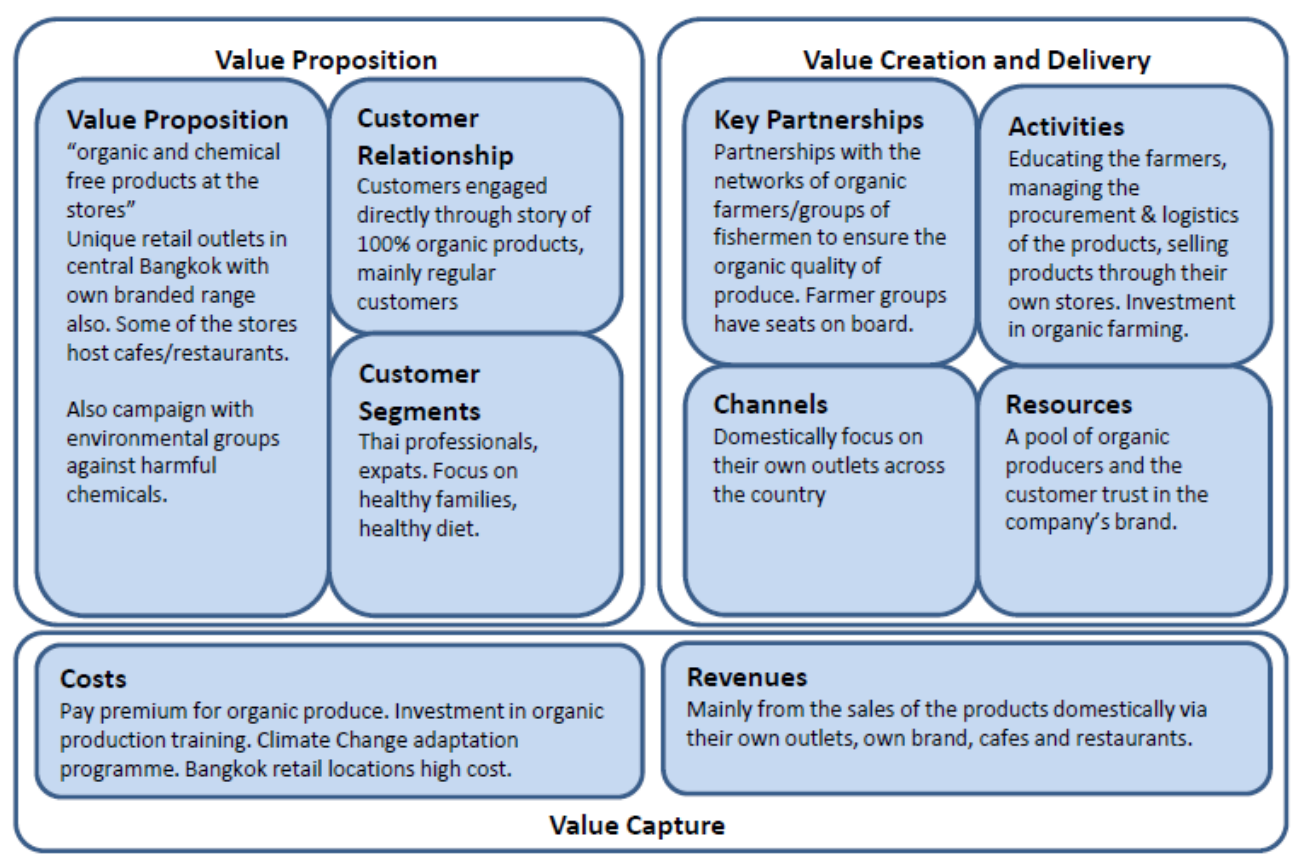

(f)

Figure 2. Cont. 


\section{Divine Chocolate Model}

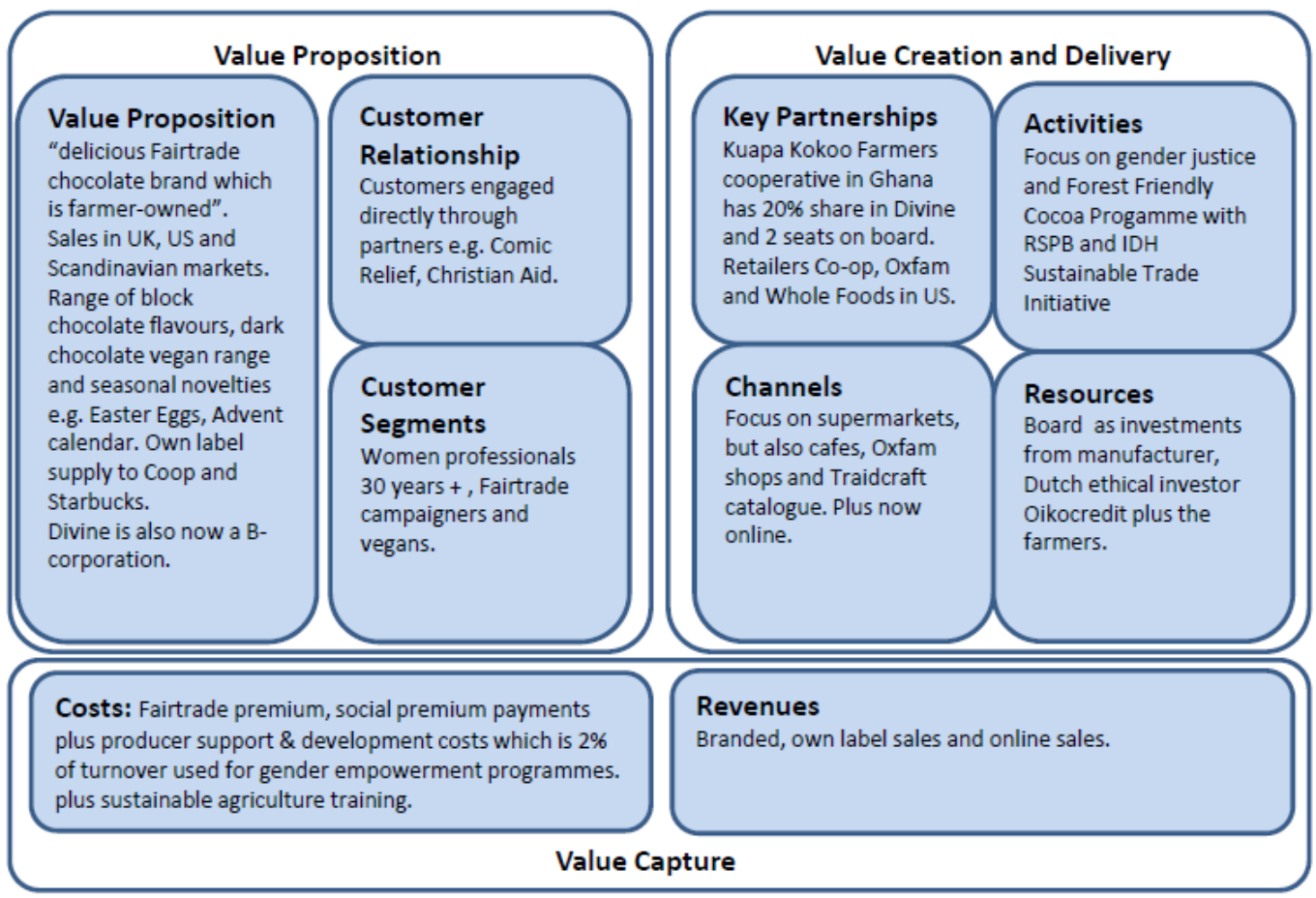

(g)

Liberation Foods Model

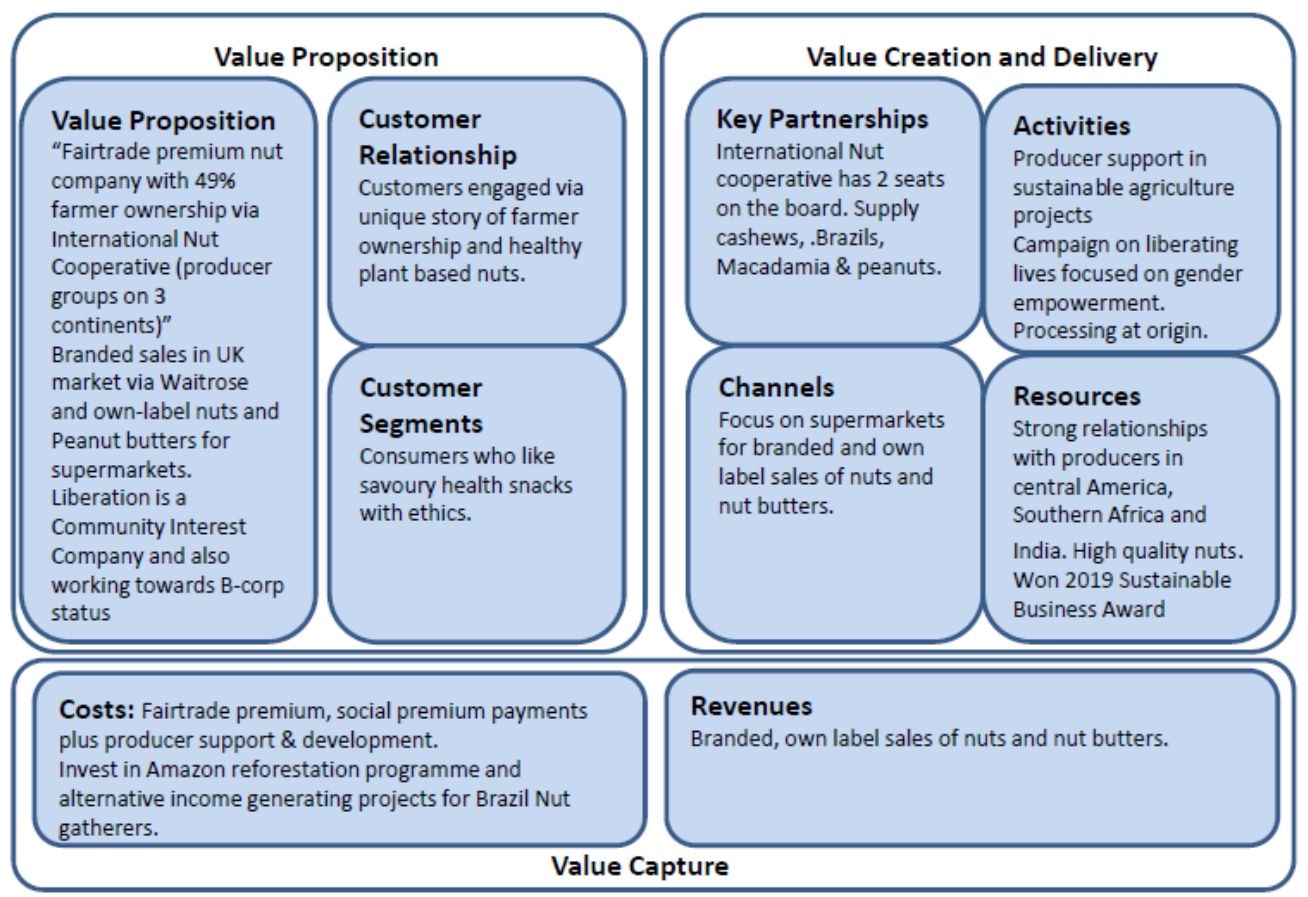

(h)

Figure 2. Cont. 


\section{Xongdur Organic Foods Business Model}

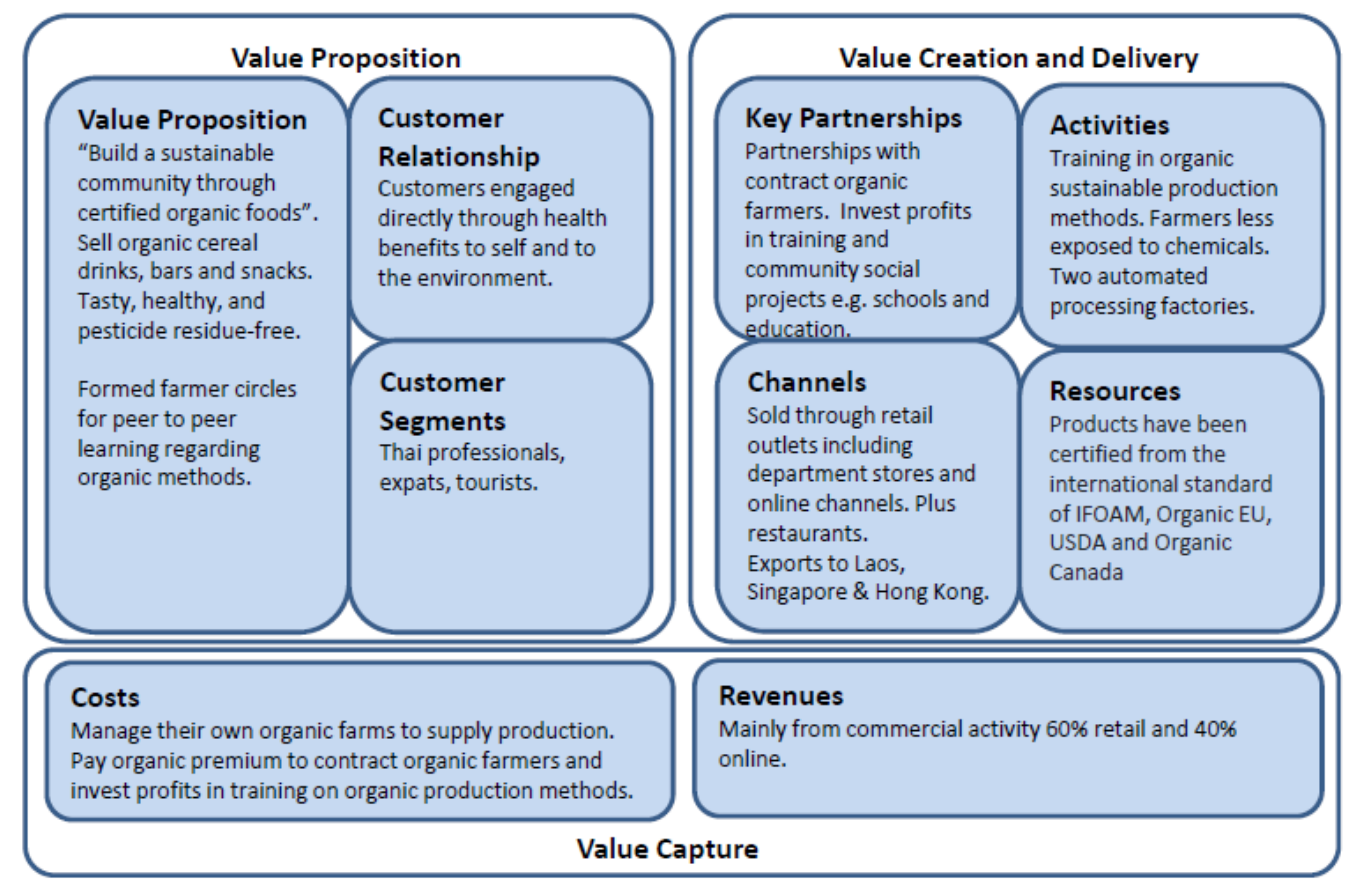

(i)

Tropical Wholefoods Business Model

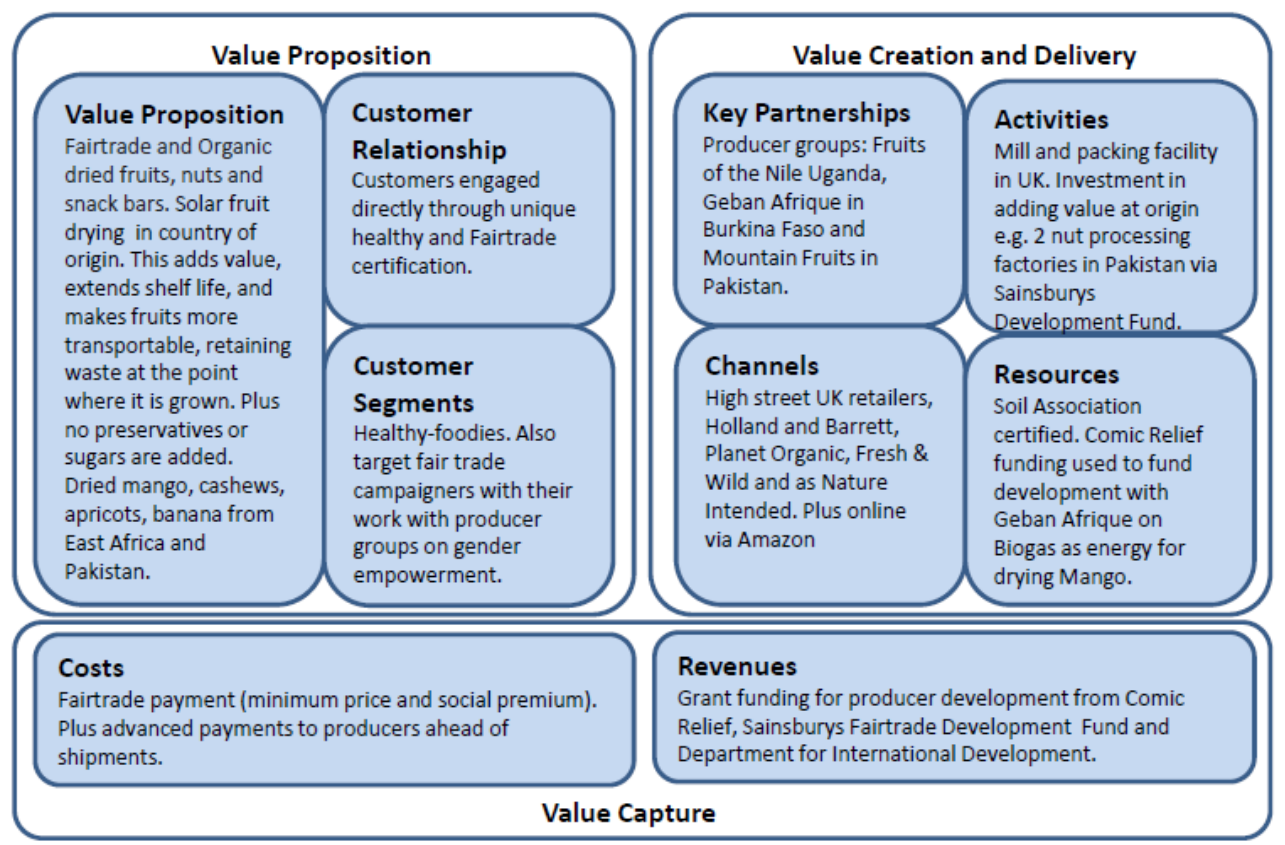

(j)

Figure 2. Ten hybrid business models.

The next stage of the analysis was to theorise conceptual categories. Working closely with the hybrid organisation, sustainable business model and IVCD literature, we ab- 
stracted twenty empirical themes and five conceptual categories from the data. Three aggregate theoretical dimensions capture how hybrids create and manage IVCD. The data structure is presented in Figure 3 below.

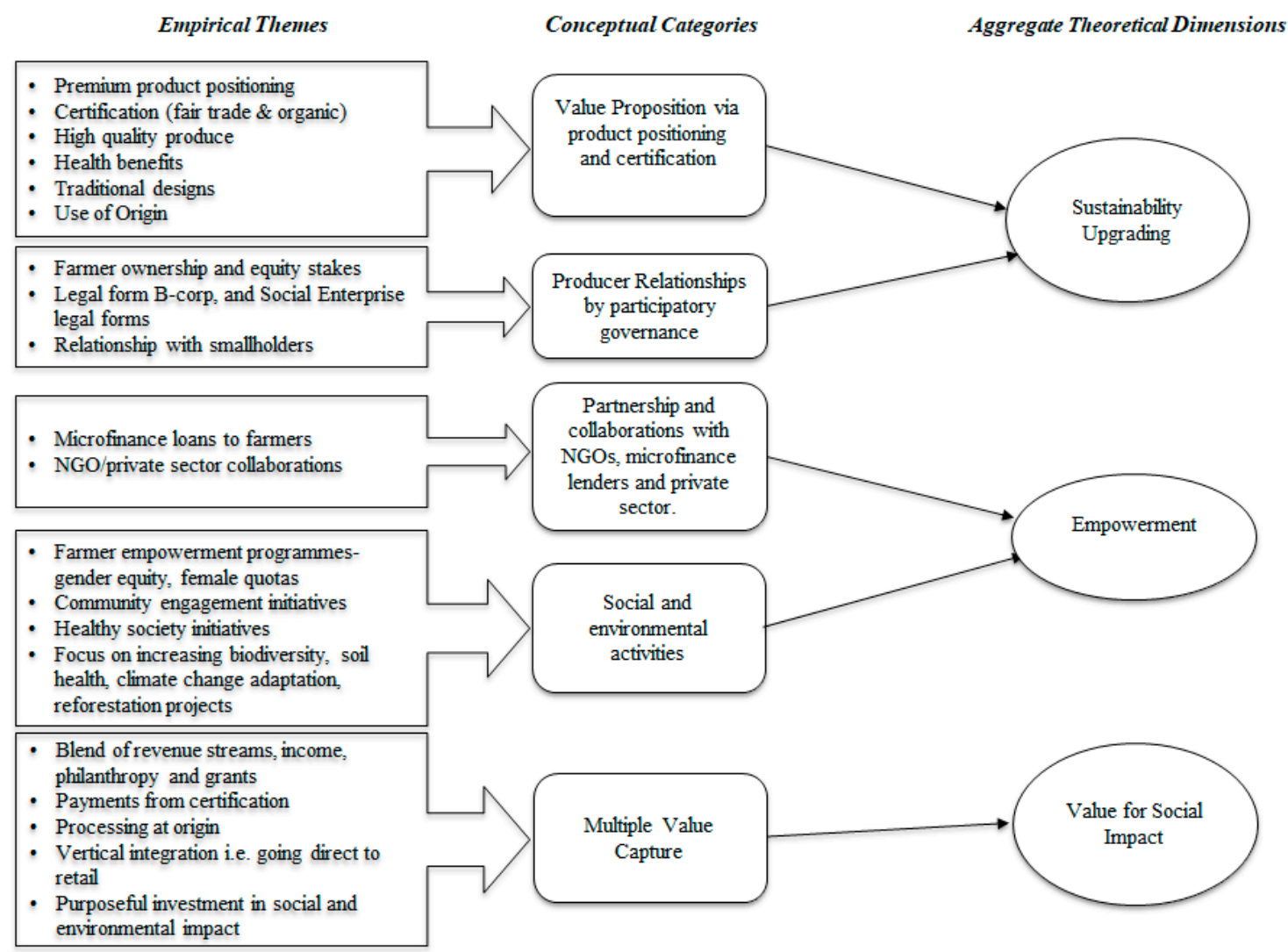

Figure 3. Data structure.

\section{Findings}

Our ten case organisations include a range of social enterprise hybrids (see Table 1) from the agrifood sector working with smallholders, including Akha Ama Coffee (Thailand), Cafédirect (UK), Dairy Home (organic dairy, Thailand), Divine Chocolate (UK), Doi Tung (community enterprises, coffee and handicrafts, Thailand), Liberation (nuts, UK), Jaspberry Organic (Jaspberry organic rice, Thailand), Lemon farm (organic food retailer, Thailand), Tropical Wholefoods (dried tropical fruits, UK) and Xongdur Organic Foods (manufacturer of organic cereal, bars, cereals, Thailand). A number of key characteristics have emerged from how these hybrids create and manage value in their business models to promote more IVCD.

\subsection{Sustainability Upgrading}

Hybrid business models achieve a social, economic and environmental value proposition by different types of upgrading, which we have termed sustainability upgrading (see Figure 3). First, a key feature of these agrifood hybrid business models is market access to premium markets by both sustainable product and process upgrading. This is achieved by a series of characteristics including product certification (organic and Fairtrade), health positioning and authenticity (origin, traditional designs, relationships with producers). This targeting of premium market segments ensures that the hybrid models can increase the value paid to smallholders.

Jaspberry Organic (see Figure 2e) packs and distributes organic certified rice under their brand "Jasberry". Their rice is claimed to have the highest antioxidant level in the world and is able to access premium rice market segments in the USA. In the case of 
Akha Ama Coffee (see Figure 2b), instead of selling the cherry and parchment coffee to intermediaries for a low price, the smallholder farmers decided to process and market the coffee themselves and established a chain of high-quality coffee bars in Chiang Mai, targeting young professionals, expats and tourists, ensuring a better price for their organic coffee and other produce. Akha Ama also roast their own coffee and their CEO explains:

"Our aim is to create more value for smallholders by integrating them into the growing, roasting and retailing of their coffee." (CEO interview, Akha Ama Coffee)

Liberation nuts (see Figure $2 \mathrm{~h}$ ) have invested fairtrade producer support and development funds to help smallholder producers invest in peanut processing facilities to redistribute economic value.

"Our peanut producers in Nicaragua are expanding their own processing facility capabilities as we speak and we're very involved in that project, feeding through the expertise so they can build their own peanut processing plant and manufacture peanut butter at origin. We're adding value back down the supply chain via both the fair trade premium and the social premium we pay." (CEO interview, Liberation)

A second characteristic of these hybrids is in terms of novel approaches to business model governance. A number of smallholder farmer groups and their workers also own equity shares in the hybrids (Dairy Home, Divine, Cafédirect, Liberation), providing a dividend when the hybrid makes a profit (see Figure $2 \mathrm{a}, \mathrm{d}, \mathrm{g}, \mathrm{h}$ ). In addition, this shareholding has also enabled some of the producer organisations to borrow money at preferential rates against the asset of equity ownership. The Chair of the Divine board explains:

"Kuapa Kokoo farmers cooperative in Ghana have been able due to their ownership of the Divine brand to borrow money at preferential rates to invest in organisational capacity building and community infrastructure." (Chair of Divine board interview)

Furthermore, the legal forms also signify to customers, investors and consumers their sustainability credentials. Three of our business models (see Figure 2 ) are already benefit corporations (Jasberry, Divine and Cafédirect); a further three are in the process of gaining benefit corporation legal status (Liberation, Akha Ama and Tropical Wholefoods). A benefit corporation is a new form of incorporation that legally places social benefits and the rights of workers, the community and the environment on an equal footing with investors and shareholders [87].

This novel approach to functional upgrading combined with product and process upgrading is designed to increase the economic, social and environmental value for smallholders. These are key characteristics of our new theoretical dimension of sustainability upgrading.

\subsection{Empowerment}

It is clear from our data that our ten hybrids, in their value creation and delivery, have constructed a set of partnerships, activities and resources with an objective to empower smallholders (see Figure 2). Hybrid owners described how their business models were explicitly intended to not only generate income for their organisation but also to promote both community economic and supply chain development. Dairy Home, Lemon Farm, Xongdur and Jaspberry Organic have grown their supply of organic produce by investing funds in supporting farmer conversion to organic production coupled with investments in farmer training. Micro-finance loans at preferential rates are brokered with microfinance organisations such as Kiva for their farmers to support farm investments. The Dairy Home (see Figure 2d) CEO explains their approach:

"When our farmers were short of cash flow and they didn't have enough credit to take loans from banks, we lent the money to them so that both their operations and ours can continue. We cannot stop our operations as there is limited amount of organic milk in the market and we are the biggest supplier. That's our commitment to the customers and the society that we have to deliver." (CEO and Founder interview, Dairy Home) 
Jaspberry Organic (see Figure 2e) also requires the farmers to keep at least $25 \%$ of their harvests for household consumption (food security), and the company guarantees the purchase of the rest of smallholders' production at a pre-agreed minimum price. Some farmers were initially concerned regarding lower yields experienced in organic production. However, both Dairy Home and Jaspberry Organic are able to focus on the economic savings made by farmers coupled with the higher premium price paid to persuade them that organic conversion is viable.

"We need to change the dairy farmers' mindset that not the amount of milk they sell and the revenue matter, but the savings they received at the end of the day plus the higher premium market price. By converting their farms into organic farms, farmers receive less milk per day but higher quality of milk and less spending on cow medicines and feeds. Hence, they receive more savings as well." (CEO and Founder interview, Dairy Home)

This enables smallholder capacity building and reduces their reliance on expensive resources.

Board-level participation by smallholders (Akha Ama, Cafédirect, Divine, Lemon Farm, Liberation and Dairy Home) is also a key characteristic in six of our case studies (see Figure 2). Such policies and practices empower beneficiaries by giving them a voice and agency in organisational strategic direction and governance coupled with increased access to resources, e.g., dividends.

"I think the ownership structure and the board are important and so the fact that the board has got cocoa farmers on it to integrate the community of beneficiaries into the ownership of the organization and decision-making structures of the organization. The whole model feels like a genuine partnership" (CEO interview, Divine)

These hybrids also allocate resources and time to activities such as training and working closely with smallholders in business development to co-create new crops, products and building community facilities (see Figure 2). This approach enables hybrids to build strong relationships with producers. The CEO of Doi Tung (Figure 2c), which works with marginalised ethnic groups in Northern Thailand, explains below.

"Initially, the people here did not trust us at all; it took us a long time to prove to them that we really wanted to help them to have better lives. Then, slowly they changed from opium growing and trading to coffee growing. Then, they started to learn how to roast and make coffee as well. Eventually, they started to see improvements in health and later in wealth and better education and future for their children" (CEO interview, Doi Tung)

One of the founding strategic objectives of Divine (see Figure 2g) was to empower female cocoa farmers in Ghana. Cocoa is seen as a "man's crop" and there is entrenched gender bias in its value chain. However, women play a crucial role in the tending and post-harvesting of cocoa, which are key to the price paid. To address this inequality, Kuapa Kokoo cocoa farmers cooperative, who are shareholders in Divine, implemented a strategy of empowerment for female cocoa farmers by setting as an objective to achieve 30 percent female participation at all decision-making levels in Kuapa Kokoo [88].

"A key decision at the outset in 1993 was to set quotas for women's participation in the cooperative with at least two representatives of the village society had to be women, plus there had to be a gender balance at both regional and national executive levels. In 2010, Kuapa Kokoo for the first time a female president" (CEO interview, Divine)

It is clear that hybrids work to readdress power imbalances and an informant from Lemon Farm (see Figure 2f) explains:

"We work closely together as equal partners with our smallholders as part of the organic participatory guarantee scheme we have set-up learning schools and allowing our organic growers through regional societies a say in the future direction of Lemon Farm" (CEO interview, Lemon Farm) 
Doi Tung provide plots of land to smallholders to build their livelihoods.

"We even divided part of our lands into small pieces and gave them all to each individual household in the village to grow the coffee and manage their own farms. What they harvested from the farms, they can sell back to us at a guaranteed price or they can sell to others, we are totally $O K$ with it because our aim is to improve their quality of life and livelihood." (Business Development Director interview, Doi Tung)

All our ten hybrids demonstrate the delivery of environmental value, which requires the design of integrated activities which build sustainability (see Figure 2). There are a series of activities including climate change adaptation work (Cafédirect), reforestation programme projects for Brazil nut gatherers in the Amazon region (Liberation) and using biogas for drying mango (Tropical Wholefoods). The Akha Ama smallholders decided to change to an organically sustainable system of mixed multi-cropping for their coffee, reducing the use of chemical fertilisers, herbicides and pesticides. The coffee plants are now grown in between larger fruit trees and a wide variety of vegetables providing produce for own consumption and selling in local markets. This system is beneficial to the soil ecology, produces humus, stabilises hillsides against erosion and retains moisture during the dry season. Due to constant crop rotation, pests are less liable to negatively affect the plants. Akha Ama have now invested in a learning school to train the next generation of social entrepreneurs. Hybrids are geared towards reinvesting in their enterprise and supply chain, rather than the capital gain aspect of a standard limited liability company. This shows a more holistic approach to working with smallholders.

"Even though I see some new business opportunity, I will not go for it if it does not help improving the lives of my village's people. To grow my business, I will not go into anything that only makes profit; it also needs to be beneficial for my community and their environment. I would rather focus on my village's people and what they are capable of, which maybe growing some fruits and vegetables. We have organised a village committee, which meets regularly to discuss any key issues with production. We also agree the annual coffee price through this committee by sharing costs of inputs etc. The leading females in the village participate actively in these discussions and often prepare the records of costs" (CEO and Founder interview, Akha Ama)

Doi Tung (Figure 2c) invests in education and schooling projects which are designed to improve the sustainability of highland communities; for adults, this increases the likelihood that their children would stay in the home community and care for them in the future.

\subsection{Value for Social Impact}

Hybrids employ a number of mechanisms to ensure that economic value is captured and is shared more equitably amongst smallholders. Firstly, a number of hybrids purposefully pay more for their raw materials from smallholders through both certification (organic and fairtrade) and agreed equitable pricing agreements. This is designed to facilitate the livelihood development of smallholder producers; fairtrade certification commits hybrids to pay fair prices for agricultural commodities. The calculation of a fairtrade price is based on providing a reasonable income to smallholder producers and does not fluctuate in the same way as conventional market prices. In fact, the fairtrade price is agreed in consultation with smallholder farmers. This aspect of smallholder participation in pricing decisions is also illustrated by Akha Ama Coffee in Northern Thailand, who explain,

"We sit down each February in a meeting with villages to agree the coffee price for that season. We share our respective costs, challenges and arrive at an agreement. It is often the women in the village who contribute most to these discussions and usually have prepared the evidence of costs and purchases" (CEO and Founder interview, Akha Ama Coffee).

Secondly, some of the hybrids studied have embedded in their memorandum and articles mechanisms to reinvest profits into smallholder development. Cafédirect have written in their memorandum and articles that $33 \%$ of operating profits are reinvested 
into their Gold Standard social and environmental development programme. Divine pay $2 \%$ of their retail sales into a producer development fund for a range of social and environmental initiatives including building schools so that there are better schools in rural areas. These programmes are often delivered in collaboration with an NGO partner, showing the importance of contingent spillover in the design of these hybrid business models in their multiple value creation and delivery.

Our informants described how the strategies that they devised were explicitly intended to not only generate income for their organisation but also to promote community economic development and empowerment. The director of an organic food company in Thailand, Xongdur Organic Foods, (see Figure 2i) comments below.

"That's the whole point of our company; our company is here to change the way that the food industry works by aiming to improve the livelihoods of farmers. So, we would not be here at all if it wasn't for that aim." (Director interview, Xongdur Organic Foods)

Third, the hybrids are adept at securing funding from a range of sources including grant funding (e.g., Tropical Wholefoods from UK-based charity Comic Relief), corporate donation (e.g., PWC to Doi Tung) and social investment (e.g., Oikocredit investment in Divine) to provide a blend of finance (see Figure 2a-j). Our informants also describe how strategies are designed to catalyse prosocial and environmental changes in commercial business practices by changing business norms. For example, a common aim of our population of hybrids is to show mainstream Fast Moving Consumer Goods (FMCG) manufacturers how trading fairly with smallholder farmers can be commercially viable.

"The mission used to be only about the livelihood of growers. It now is also about product and about business pioneering as well." (CEO interview, Doi Tung)

\section{Discussion}

The general conception of IVCD is "positive or desirable change in a value chain to extend or improve productive operations and generate social benefits such as poverty reduction, income and employment generation, economic growth, environmental performance, gender equity and other development goals" [1].

This study shows how social enterprise hybrids are able to address a number of challenges identified in the IVCD literature including power imbalances, capacity building (organisational and community), access to both credit and markets and gender equity [34]. Hybrid business models create a value proposition that delivers sustainability upgrading for smallholders via product, process and governance upgrades, which empower smallholders to achieve development goals and create multiple value for social impact. First, sustainability upgrading to access higher valued markets is achieved via product certification or leveraging origin and authenticity, whilst also being more integrated in the value chain via novel governance approaches (e.g., equity ownership) or by owning processing or retailing facilities. This mix of activities shows how multiple values, particularly economic value, can be created for smallholders. A further characteristic that can be added to the business model to support sustainability upgrading is the organisational legal form e.g., B-corporation, which ensures a focus on social impact. In addition, the purposeful use of microloans, i.e., access to credit, helps smallholders to invest in key strategies such as organic conversion. Providing this type of access to credit does not assume that smallholders have the financial resources to invest in these types of initiatives [1].

Second, the evidence shows that a focus on empowering smallholders is a key characteristic of how social enterprise hybrids both create and manage value chains. According to [43], empowerment is conceptualised in terms of three different forms of power including power within, i.e., sense of self-esteem and worth, power capabilities and power with collective action to achieve more than is possible for an individual alone. Empowerment is the transfer or acquisition of power, be it by an individual or a group $[42,89,90]$. This may involve the process of capacity building, which increases the participation and decision-making power of individuals and groups and may potentially lead to transformative action [91]. Equity ownership for producer groups, and gender empowerment 
programmes and quotas for female representation at producer organisational level, clearly target both power imbalances and gender equity within value chains. Equity ownership provides a voice and agency via board representation and also an asset which financial investment can be borrowed against. This clearly provides empowerment due to increased decision-making power for smallholders. A range of business model structures are created to facilitate the participation of smallholders in key decision-making processes including regional societies to discuss community development, village meetings to discuss annual pricing, smallholder board representation and producer foundations to raise programme funding. This research responds to the call by the authors of [92], who argue that there is a scarcity of studies on empowerment in value chains.

Third, creating value to increase social impact and improve smallholder livelihoods is a key characteristic of hybrid business models. This is done through a variety of approaches which bring together a range of financial resources, including higher prices paid to smallholders for raw materials, specific clauses in company memorandum and articles to ensure that additional funds are paid to smallholders, coupled with the ability of these hybrid business models to secure funding from a range of sources. A number of the hybrids studied commit additional profit for reinvestment in social and environmental programmes, e.g., Cafédirect (Figure 2a), with $33 \%$ of its operating profit being invested in Producers Direct. This is then used to fund a range of social and environmental programmes, often in collaboration with NGOs, charities and government agencies to deliver social and environmental impact via contingent value spillover. These hybrid business models are also adept at securing funds from commercial, grant and social investment sources, providing a blend of investment, e.g., Tropical Wholefoods (Figure 2j) has secured funds from UK Charity Comic Relief, Sainsbury's Fairtrade Development Fund and the former UK Department for International Development for a range of programmes to scale up social impact.

Our analysis enriches the concept of ICVD by theorising the ways in which social enterprise hybrids create and manage value chains. This hybrid-driven approach to IVCD enriches this concept beyond the narrow technical innovation and economic focus which currently dominates this literature. We bring empowerment, sustainable upgrading, improved distribution of economic value, reinvestment of profits in creating social and environmental impact and novel governance arrangements to this literature as important features of building inclusive value chains.

\section{Conclusions}

This research answers the call by previous authors who argue that there has been limited research on how business models can be designed to integrate smallholders into value chains in more inclusive ways $[6,15,93]$. We contribute to the literature on IVCD, sustainable business models and hybrids by utilising the business model canvas to identify the business model characteristics that hybrid organisations use to create and manage IVCD.

It is clear that hybrid business models are able to meet the challenges for incorporating smallholders into value chains identified in the IVCD literature. Hybrids achieve this by more inclusive approaches to value chain sustainability upgrading, novel approaches to governance and empowerment and creating value for social impact. Returning to our research question, How do hybrids create and manage value chain development?, social enterprise hybrids, when creating value chains, work to address power imbalances such as gender inequality and deliver social benefits due to their social mission. They do this by a number of business model characteristics, including designing equitable pricing arrangements in discussion with farmers, e.g., fairtrade certification, providing credit arrangements at preferential rates and access to premium market segments. Our research shows how hybrids provide the financial investment necessary to build IVCD.

Hybrids also purposefully allocate funds to build producer empowerment activities to ensure the capacity building of farmer organisations, work on food security, gender equality, education and environmental programmes to build agency for smallholders. Fur- 
thermore, new approaches to governance, legal form (benefit corporations) and ownership are employed by hybrids to develop more inclusive value chains that target positive social and environmental change. Equity ownership for producer groups, increasing their economic value received, coupled with gender empowerment programmes and quotas for female representation at the producer organisational level, clearly target power imbalances within value chains. These aspects of individual and collective empowerment are a new contribution to both the hybrid organising and IVCD literature. Moreover, some producer groups are going direct to market via their own social enterprise retail outlets, e.g., Aka Ahma Coffee (Figure 2b), reducing the economic value taken by intermediaries in the value chain. Social enterprises, due to their multi-stakeholder approach, appear to be well placed to collaborate and develop activities and partnerships with NGOs and other partners to create multiple value in the delivery of both social and environmental programmes. These identified characteristics provide a useful contribution to the IVCD literature, showing the importance of hybrid business models in delivering positive social and environmental value.

This paper also appears to answer the recent call in Nature for more research on appropriate business solutions for smallholder farmers to address growing problems of food insecurity and poverty. The business models developed in Figure 2 provide important templates for both practitioners and policymakers planning or striving to achieve more IVCD. Furthermore, we have also shown the potential of value chain perspectives for future research into social enterprises. Gary [94] was the first to use the term governance in his influential contribution to "Commodity Chains and Global Capitalism" [94]. Here, in [94], governance is defined as the "authority and power relationships that determine how financial, material and human resources are allocated and flow within a chain". On this basis, Gereffi distinguished between "producer-driven" and "buyer-driven" chains and argued that barriers to entry constitute the key determinant of the "governance structure" of these chains. The dominant questions in most global value chain (GVC) scholarship centre on the generation, control and distribution of economic value. Whilst not dismissing the importance of these questions, we have cast the net wider to consider the role that social enterprise hybrids can play in addressing the imbalances and governance tensions in value chains. The "hybrid-driven value chains" studied here demonstrate how more inclusive participatory approaches can be more effective in achieving development goals. Future studies on the role of social enterprise hybrids in regional or international supply chains could be enhanced by applying a value chain approach to deepen our understanding of how hybrids create economic, social and environmental value. This analysis could also provide valuable lessons to those more enlightened corporate firms who are aiming to make a positive contribution to achieving sustainable development goal targets by working with smallholders in a more collaborative way. Furthermore, this paper has focused on empirical evidence sourced from hybrid leaders; future research could also seek the view of smallholder farmer leaders.

Author Contributions: Investigation, P.K.-N.; writing—original draft, B.D. All authors have read and agreed to the published version of the manuscript.

Funding: This research received no external funding.

Institutional Review Board Statement: The study was conducted according to the guidelines of the Declaration of Helsinki, and approved by the University of York Ethics Committee on the 26 April 2018.

Informed Consent Statement: Informed consent was obtained from all subjects involved in the study.

Data Availability Statement: The data presented in this study are available on request from the corresponding author. The data are not publicly available due to anonymity of respondents. 
Acknowledgments: The authors would like to thank our funders, Thammasat Business School and Thammasat University for their research funding to study the management of social enterprises in both Thailand and the UK. In addition, the Biotechnology and Biological Sciences Research Council: BB/N02060X/1. Furthermore, we would like to thank the social enterprise organisations for their support and collaboration.

Conflicts of Interest: The authors declare no conflict of interest.

\section{References}

1. Devaux, A.; Torero, M.; Donovan, J.; Horton, D. Agricultural innovation and inclusive value-chain development: A review. J. Agribus. Dev. Emerg. Econ. 2018, 8, 99-123. [CrossRef]

2. Donovan, J.; Franzel, S.; Cunha, M.; Gyau, A.; Mithöfer, D. Guides for value chain development: A comparative review. J. Agribus. Dev. Emerg. Econ. 2015, 5, 2-23. [CrossRef]

3. Orr, A.; Donovan, J.; Stoian, D. Smallholder value chains as complex adaptive systems: A conceptual framework. J. Agribus. Dev. Emerg. Econ. 2018, 8, 14-33. [CrossRef]

4. Haggblade, S.; Theriault, V.; Staatz, J.; Dembele, N.; Diallo, B. A Conceptual Framework for Promoting Inclusive Agricultural Value Chains. Available online: http:/ / citeseerx.ist.psu.edu/viewdoc/download?doi=10.1.1.420.1747\&rep=rep1\&type=pdf (accessed on 5 January 2021).

5. Norese, M.F.; Corazza, L.; Bruschi, F.; Cisi, M. A multiple criteria approach to map ecological-inclusive business models for sustainable development. Int. J. Sustain. Dev. World 2020, 28, 75-91. [CrossRef]

6. Agyekumhene, C.; De Vries, J.; Paassen, A.V.; Schut, M.; MacNaghten, P. Making Smallholder Value Chain Partnerships Inclusive: Exploring Digital Farm Monitoring through Farmer Friendly Smartphone Platforms. Sustainability 2020, 12, 4580. [CrossRef]

7. Asikin, Z.; Baker, D.; Villano, R.; Daryanto, A. Business Models and Innovation in the Indonesian Smallholder Beef Value Chain. Sustainability 2020, 12, 7020. [CrossRef]

8. Candelo, E.; Casalegno, C.; Civera, C.; Mosca, F. Turning farmers into business partners through value co-creation projects. Insights from the coffee supply chain. Sustainability 2018, 10, 1018. [CrossRef]

9. International Trade Forum. Routes to inclusive and sustainable trade. In International Trade Forum 4; International Trade Centre: Geneva, Switzerland, 2017.

10. Oxfam. Ripe for Change: Ending Human Suffering in Supermarket Supply Chains; Oxfam GB for Oxfam International: Oxford, UK, 2018.

11. Bacon, C.; Sundstrom, W.A.; Eugenia, M.E.F.; Gomez, F.; Mendez, V.E.; Santos, R.; Goldoftas, B.; Dougherty, I. Explaining the 'hungry farmer paradox': Smallholders and fair-trade cooperatives navigate seasonality and change in Nicaragua's corn and coffee markets. Glob. Environ. Chang. 2014, 25, 133-149. [CrossRef]

12. Wangu, J.; Mangnus, E.; van Westen, A.C. Limitations of Inclusive Agribusiness in Contributing to Food and Nutrition Security in a Smallholder Community. A Case of Mango Initiative in Makueni County, Kenya. Sustainability 2020, 12, 5521. [CrossRef]

13. FAO. Resilient Livelihoods_Disaster Risk Reduction for Food and Nutrition Security Framework Programme; FAO: Rome, Italy, 2013.

14. Nature Editorial. Ending Hunger: Science must stop neglecting smallholder farmers. Nature 2020, 586, 336. [CrossRef]

15. Danse, M.; Klerkx, L.; Reintjes, J.; Rabbinge, R.; Leeuwis, C. Unravelling inclusive business models for achieving food and nutrition security in BOP markets. Glob. Food Secur. 2020, 24, 100354. [CrossRef]

16. Kannothra, C.G.; Manning, S.; Haigh, N. How hybrids manage growth and social-business tensions in global supply chains: The case of impact sourcing. J. Bus. Ethics 2018, 148, 271-290. [CrossRef]

17. Bocken, N.M.P.; Short, S.W.; Rana, P.; Evans, S. A literature and practice review to develop sustainable business model archetypes. J. Clean. Prod. 2014, 65, 42-56. [CrossRef]

18. Rauter, R.; Jonker, J.; Baumgartner, R.J. Going one's own way: Drivers in developing business models for sustainability. J. Clean. Prod. 2017, 140, 144-154. [CrossRef]

19. Davies, I.A.; Chambers, L. Integrating hybridity and business model theory in sustainable entrepreneurship. J. Clean. Prod. 2018, 177, 378-386. [CrossRef]

20. Davies, I.A.; Doherty, B. Balancing a hybrid business model: The search for equilibrium at Cafédirect. J. Bus. Ethics 2019, 157, 1043-1066. [CrossRef]

21. Billis, D. Hybrid Organizations for the Third Sector. Challenges for Practice, Theory, and Policy; Palgrave Macmillan: London, UK, 2010.

22. Doherty, B.; Haugh, H.; Lyon, F. Social enterprises as hybrid organizations: A review and research agenda. Int. J. Manag. Rev. 2014, 16, 417-436. [CrossRef]

23. Pache, A.C.; Santos, F. Inside the hybrid organization: Selective coupling as a response to competing institutional logics. Acad. Manag. J. 2013, 56, 972-1001. [CrossRef]

24. Zahra, S.A.; Gedajlovic, E.; Neubaum, D.O.; Shulman, J.M. A typology of social entrepreneurs: Motives, search processes and ethical challenges. J. Bus. Ventur. 2009, 24, 519-532. [CrossRef]

25. Stephan, U.; Patterson, M.; Kelly, C.; Mair, J. Organizations driving positive social change: A review and an integrative framework of change processes. J. Manag. 2016, 42, 1250-1281. [CrossRef]

26. Bacon, C.M. Confronting the coffee crisis: Can fair trade, organic, and specialty coffees reduce small-scale farmer vulnerability in northern Nicaragua? World Dev. 2005, 33, 497-511. [CrossRef] 
27. Gereffi, G.; Humphrey, J.; Sturgeon, T. The governance of global value chains. Rev. Int. Political Econ. 2005, 12, 78-104. [CrossRef]

28. Lambert, D.; Pohlen, T. Supply Chain metrics. Int. J. Logist. Manag. 2001, 12, 1-19. [CrossRef]

29. Reardon, T.; Timmer, C.P. The economics of the food system revolution. Annu. Rev. Resour. Econ. 2012, 4, 225-264. [CrossRef]

30. Rigg, J.; Salamanca, A.; Phongsir, M.; Sripun, M. More farmers less farming? Understanding the truncated agrarian transitions in Thailand. World Dev. 2018, 107, 327-337. [CrossRef]

31. Knorringa, P.; Pegler, L. Globalisation, firm upgrading and impacts on labour. Tijdschr. Econ. Soc. Geogr. 2006, 97, 470-479. [CrossRef]

32. Stoian, D.; Donovan, J.; Fisk, J.; Muldoon, M. Value chain development for rural poverty reduction: A reality check and a warning. Enterp. Dev. Microfinanc. 2012, 23, 54-60. [CrossRef]

33. Doherty, B.; Tranchell, S. New thinking in international trade? A case study of The Day Chocolate Company. Sustain. Dev. 2005, 13, 166-176. [CrossRef]

34. Donovan, J.; Stoian, D.; Poe, K. Value chain development in Nicaragua: Prevailing approaches and tools used for design and implementation. Enterp. Dev. Microfinanc. 2017, 28, 10-27. [CrossRef]

35. Minot, N.; Sawyer, B. Contract farming in developing countries: Theory, practice, and policy implications. In Innovation for Inclusive Value Chain Development: Successes and Challenges; Devaux, A., Torero, M., Donovan, J., Horton, D.E., Eds.; International Food Policy Research Institute: Washington, DC, USA, 2016; pp. 127-155.

36. Tiffen, P. A chocolate-coated case for alternative international business models. Dev. Pract. 2002, 12, 383-397. [CrossRef]

37. Donovan, J.; Poole, N. Changing asset endowments and smallholder participation in higher value markets: Evidence from certified coffee producers in Nicaragua. Food Policy 2014, 44, 1-3. [CrossRef]

38. Ayele, S.; Duncan, A.; Larbi, A.; Khanh, T.T. Enhancing innovation in livestock value chains through networks: Lessons from fodder innovation case studies in developing countries. Sci. Public Policy 2012, 39, 333-346. [CrossRef]

39. Thiele, G.; Devaux, A.; Reinoso, I.; Pico, H.; Montesdeoca, F.; Pumisacho, M.; Horton, D. Multi-stakeholder platforms for linking small farmers to value chains: Evidence from the Andes. Int. J. Agric. Sustain. 2011, 9, 423-433. [CrossRef]

40. Swaans, K.; Cullen, B.; Van Rooyen, A.F.; Adekunle, A.; Ngwenya, H.; Lema, Z.; Nederlof, S. Dealing with critical challenges in African innovation platforms: Lessons for facilitation. Knowl. Manag. Dev. J. 2013, 9, 116-135.

41. Saenger, C.; Torero, M.; Qaim, M. Impact of third-party contract enforcement in agricultural markets-A field experiment in Vietnam. Am. J. Agric. Econ. 2014, 96, 1220-1238. [CrossRef]

42. Kabeer, N. The Power to Choose: Bangladeshi Women and Labour Market Decisions in London and Dhaka; Verso: London, UK, 2000.

43. Mosedale, S. Assessing women's empowerment: Towards a conceptual framework. J. Int. Dev. 2005, 17, 243-257. [CrossRef]

44. Mair, J.; Marti, I. Social entrepreneurship research: A source of explanation, prediction and delight. J. World Bus. 2006, 41, 36-44. [CrossRef]

45. Lumpkin, G.T.; Moss, T.W.; Gras, D.M.; Kato, S.; Amezcua, A.S. Entrepreneurial processes in social contexts: How are they different, if at all? Small Bus. Econ. 2013, 40,761-783. [CrossRef]

46. Defourny, J.; Nyssens, M. Conceptions of social enterprise in Europe and the United States: Convergences and divergences. Soc. Enterp. J. 2006, 1, 32-53.

47. Teasdale, S. Negotiating tensions: How do social enterprises in the homelessness field balance social and commercial considerations? Hous. Stud. 2012, 27, 514-532. [CrossRef]

48. Mason, C.; Doherty, B. A fair trade-off? Paradoxes in the governance of fair-trade social enterprises. J. Bus. Ethics 2016, 136, 451-469. [CrossRef]

49. Austin, J.; Stevenson, H.; Wei-Skillern, J. Social and commercial entrepreneurship: Same, different or both? Entrep. Theory Pract. 2006, 30, 1-22. [CrossRef]

50. Vickers, I.; Lyon, F. Beyond green niches? Growth strategies of environmentally-motivated social enterprises. Int. Small Bus. J. 2013, 32, 449-470. [CrossRef]

51. Gillett, A.; Loader, K.; Doherty, B.; Scott, J.M. An examination of tensions in a hybrid collaboration: A longitudinal study of an empty homes project. J. Bus. Ethics 2018, 157, 949-967. [CrossRef]

52. Montgomery, A.W.; Dacin, P.A.; Dacin, M.T. Collective social entrepreneurship: Collaboratively shaping social good. J. Bus. Ethics 2012, 111, 375-388. [CrossRef]

53. Maak, T.; Stoetter, N. Social Entrepreneurs as responsible leaders: 'Fundación Paraguya' and the case of Martin Burt. J. Bus. Ethics 2012, 111, 413-430. [CrossRef]

54. Mair, J.; Battilana, J.; Cardenas, J. Organizing for society: A typology of social entrepreneuring models. J. Bus. Ethics 2012, 111, 353-373. [CrossRef]

55. Crittenden, W.F.; Crittenden, V.L. Strategic planning in third-sector organizations. J. Manag. Issues 1997, 9, 86-103.

56. Haigh, N.; Hoffman, A.J. Hybrid organizations. Organ. Dyn. 2012, 41, 126-134. [CrossRef]

57. Somerville, P.; McElwee, G. Situating community enterprise: A theoretical explanation. Entrep. Region. Dev. 2011, 23, 317-330. [CrossRef]

58. Zuckerman, E. The categorical imperative: Securities analysts and the illegitimacy discount. Am. J. Sociol. 1999, 104, 1398-1438. [CrossRef]

59. Hansmann, H.B. The role of non-profit enterprise. Yale Law J. 1980, 89, 835-898. [CrossRef] 
60. Battilana, J.; Lee, M. Advancing research on hybrid organizing. Insights from the study of social enterprises. Acad. Manag. Ann. 2014, 8, 397-441. [CrossRef]

61. Dees, J.G.; Elias, J. The challenges of combining social and commercial enterprise. Bus. Ethics Q. 1998, 8, 165-178.

62. Santos, F.; Pache, A.C.; Birkholz, C. Making hybrids work: Aligning business models and organizational design for social enterprises. Calif. Manag. Rev. 2015, 57, 36-58. [CrossRef]

63. Smith, W.K.; Tracey, P. Institutional complexity and paradox theory: Complementarities of competing demands. Strateg. Organ. 2016, 14, 455-466. [CrossRef]

64. Wry, T.; Zhao, E.Y. Taking Trade-offs Seriously: Examining the Contextually Contingent Relationship Between Social Outreach Intensity and Financial Sustainability in Global Microfinance. Organ. Sci. 2018, 29. [CrossRef]

65. Osterwalder, A.; Pigneur, Y.; Tucci, C.L. Clarifying business models: Origins, present, and future of the concept. Commun. Assoc. Inf. Syst. 2005, 16, 1-25. [CrossRef]

66. Teece, D. Business models, business strategy and innovation. Long Range Plan. 2010, 43, 172-194. [CrossRef]

67. Boons, F.; Lüdeke-Freund, F. Business models for sustainable innovation: State-of-the-art and steps towards a research agenda. J. Clean. Prod. 2013, 45, 9-19. [CrossRef]

68. Zott, C.; Amit, R.; Massa, L. The business model: Recent developments and future research. J. Manag. 2011, 37, 1019-1042.

69. Margiono, A.; Zolin, R.; Chang, A. A typology of social venture business model configurations. Int. J. Entrep. Behav. Res. 2018, 24, 626-650. [CrossRef]

70. Osterwalder, A.; Pigneur, Y. Business Model Generation: A Handbook for Visionaries, Game Changers, and Challengers; John Wiley \& Sons: Hoboken, NJ, USA, 2010.

71. Richardson, J. The business model: An integrative framework for strategy execution. Strateg. Chang. 2008, 17, 133-144. [CrossRef]

72. França, C.L.; Broman, G.; Robèrt, K.-H.; Basile, G.; Trygg, L. An approach to business model innovation and design for strategic sustainable development. J. Clean. Prod. 2016, 140, 33-52. [CrossRef]

73. Geissdoerfer, M.; Bocken, N.M.P.; Hultink, E.J. Design thinking to enhance the sustainable business modelling process-A workshop based on a value mapping process. J. Clean. Prod. 2016, 135, 1218-1232. [CrossRef]

74. Joyce, A.; Paquin, R.L. The triple layered business model canvas: A tool to design more sustainable business models. J. Clean. Prod. 2016, 135, 1474-1486. [CrossRef]

75. Upward, A.; Jones, P. An Ontology for Strongly Sustainable Business Models Defining an Enterprise Framework Compatible with Natural and Social Science. Organ. Environ. 2015, 29, 97-123. [CrossRef]

76. Paroutis, S.; Heracleous, L. Discourse revisited: Dimensions and employment of first order discourse during institutional adoption. Strateg. Manag. J. 2013, 34, 935-956. [CrossRef]

77. Strauss, A.; Corbin, J. Basics of Qualitative Research; Sage Publications: Thousand Oaks, CA, USA, 1990.

78. Eisenhardt, K.M.; Graebner, M.E. Theory building from cases: Opportunities and challenges. Acad. Manag. J. 2007, 50, 25-32. [CrossRef]

79. Voss, C. Case research in operations management. In Researching Operations Management; Karlsson, C., Ed.; Routledge: London, UK, 2010; pp. 176-209.

80. Yin, R.K. Case Study Research: Design and Methods, 3rd ed.; SAGE Publications, Inc.: Thousand Oaks, CA, USA, 2003.

81. Eisenhardt, K.M. Agency theory: An assessment and review. Acad. Manag. Rev. 1989, 14, 57-74. [CrossRef]

82. Doherty, B.; Kittipanya-Ngam, P. The Emergence and Contested Growth of Social Enterprise in Thailand. J. Asian Public Policy 2020. [CrossRef]

83. Friend, R.M.; Thankappan, S.; Doherty, B. Agricultural and food systems in the Mekong region: Drivers of transformation and pathways of change. Emerald Open Res. 2019. [CrossRef]

84. Barnes, D.M. An analysis of the grounded theory method and the concept of culture. Qual. Health Res. 1996, 6, 429-441. [CrossRef]

85. Askey, H.; Knight, P. Interviewing for Social Scientists; Sage Publications: London, UK, 1999.

86. Spiggle, S. Analysis and interpretation of qualitative data in consumer research. J. Consum. Res. 1994, 21, 491-503. [CrossRef]

87. Marquis, C. Better Business: How the B Corp Movement Is Remaking Capitalism; Yale University Press: London, UK, 2020.

88. Doherty, B. Gender Equality and Women's Empowerment through Fair Trade Social Enterprise: Case of Divine Chocolate and Kuapa Kokoo. In Entrepreneurship and the Sustainable Development Goals Vol: 8; Apostolopoulos, N., Al-Dajani, H., Holt, D., Jones, P., Newbury, R., Eds.; Emerald Publishing Ltd.: Bingley, UK, 2018; Chapter 9; pp. 151-164. [CrossRef]

89. McEwan, C.; Bek, D. (Re)politicising empowerment: Lessons from the South African wine industry. Geoforum 2006, 37, 1021-1034. [CrossRef]

90. Rowlands, J. Questioning Empowerment: Working with Women in Honduras; Oxfam: Oxford, UK, 1997.

91. Anderson, J.; Siim, B. Introduction: The politics of inclusion and empowerment: Gender class and citizenship. In The Politics of Inclusion and Empowerment: Gender, Class and Citizenship; Anderson, J., Siim, B., Eds.; Palgrave Macmillan: London, UK, 2004; Chapter 1; pp. 1-18.

92. Said-Allsopp, M.; Tallontire, A. Pathways to empowerment? Dynamics of women's participation in Global Value Chains. J. Clean. Prod. 2015, 107, 114-121. [CrossRef] 
93. Kilelu, C.W.; Klerkx, L.; Leeuwis, C. Supporting smallholder commercialisation by enhancing integrated coordination in agrifood value chains: Experiences with dairy hubs in Kenya. Exp. Agric. 2017, 53, 269-287. [CrossRef]

94. Gereffi, G. The Organization of Buyer-Driven Global Commodity Chains: How, U.S. Retailers Shape Overseas Production Networks. In Commodity Chains and Global Capitalism; Gereffi, G., Korzeniewicz, M., Eds.; Praeger Publishers: Westport, CT, USA, 1994; p. 97. 